\title{
Direct Determination of Sulfacetamide Sodium by Derivative UV Spectrophotometry
}

\author{
Isam J. Al-Nuri \\ Israa' A. Al-Obaydi \\ Department of Chemistry \\ College of Science \\ Mosul University
}

(Received 25 / 11 / 2008 ; Accepted 15 / 6 / 2009)

\begin{abstract}
UV Derivative spectra were used for the direct quantitative determination of sulfacetamide sodium in distilled water. The quantification was accomplished using the integrated area under the peaks. The zero-order spectrum of sulfacetamide sodium shows an absorption band at $\lambda=258 \mathrm{~nm}$, with an $\varepsilon_{\max }=149001 . \mathrm{mol}^{-1} . \mathrm{cm}^{-1}$, the determination limit was $(0.55-25.4) \mu \mathrm{g} / \mathrm{ml}$ with $\mathrm{R}^{2}=0.9999$ and $\mathrm{RSD}=1.25 \%$.

The determination limits were $(0.25-50.80) \mu \mathrm{g} / \mathrm{ml}$ for both first and second-order derivatives with $\mathrm{R}^{2}=0.9982,0.9995$ and $\mathrm{RSD}=1.60 \%, 2.40 \%$ respectively. This indicates a more sensitive and accurate results as compared with the zero-order method. These methods were applied to the direct determination of the samacetamide eye drop.

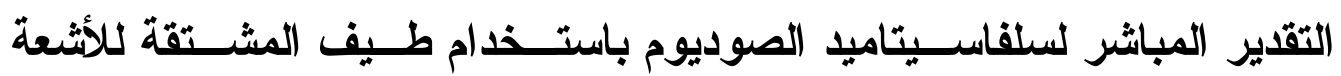

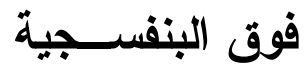

المـلخــص

يتضمن البحث طريقة مبانثرة لتقدير سلفاسيتاميد الصوديوم في الماء المقطر باستهــام طـيف

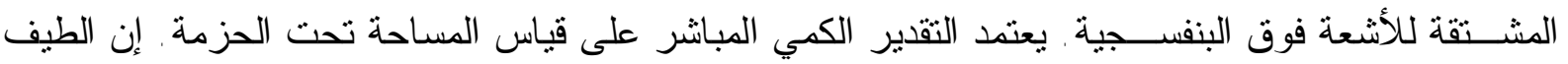
الاعتيادي (zero-order spectra) يظهر حزمة امتصاص عند الطول ألموجي 258 نانوميتر و بمعامل

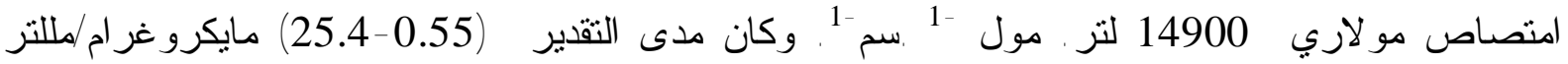
. $\mathrm{RSD}=1.25 \%, \mathrm{R}^{2}=0.9999$,

أما عند التقدير المباثر باستخدام طيف المشنقة الأولى و الثانية فقد أظهرت مدى تقدير

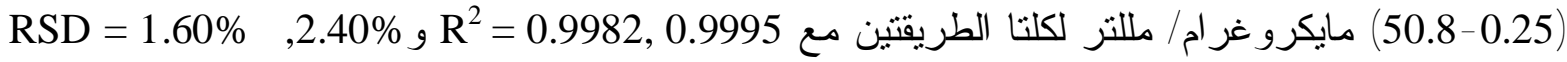
على التو الي، مما يدل على زيادة في مدى التقدير و ان الطريقة حساسة و دقيقة، وقد استخدمت هذه الطر ائق
} 
في التقدير المباتر لدواء SAMACETAMIDE المستخدم كقطرة عين و أظهرت النتائج نجاح هذه الطر ائق .

\section{INTRODUCTION}

The spectrum of any compound may be considered as a mathematical function relating the absorbance to the wavelength of a particular compound. Thus

$$
A=f(\lambda)
$$

The function $\mathrm{f}$ includes all parameters which affect the absorbance of the compound such as concentration, cell path length, etc., as well as, the molar absorptivity of the compound at all wavelengths in the spectrum.

Most UV/Visible spectra may be considered to be made up of a series of overlapping Gaussian peaks. It is therefore, of interest to consider what happens to Gaussian function when it is differentiated. Figure 1 shows such a peak, with its first, second, third and fourth derivatives.

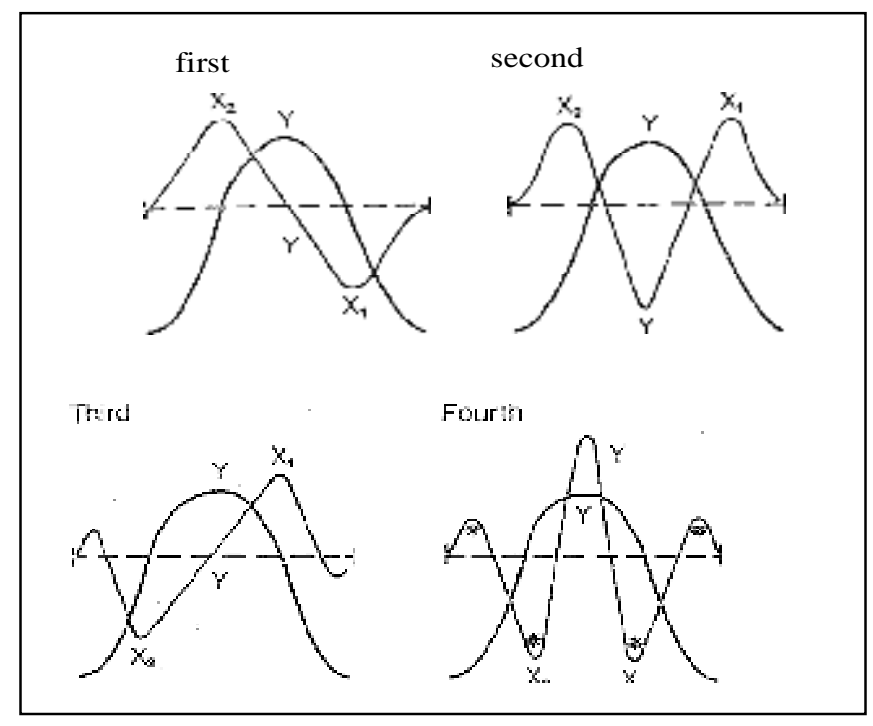

Fig. 1: Idealised representation of 1st/4th derivative on Gaussian peak.

One of the classic analytical problems for any researcher in the field of UV/Visible spectrophotometry is the resolution of a number of components in a mixture, particularly when the absorbance of those components is extremely variable and/or components with naturally narrow absorption bands are overlapped by components with wide absorption bands. The problem is to resolve small shoulders or peaks from the total spectrum.

This is one of the applications of derivative spectroscopy beside the improved spectral resolution, precise $\lambda_{\max }$ determination, elimination of background turbidity and improving detection limit (Himmadi, 2007). 
$\mathrm{N}$-acetylsulfonamide or sodium derivative of $\mathrm{N}$-[(4-aminophenyl) sulphonyl] acetamide (Maffat et al.,2005) is called sulfacetamide. It is a medicine used to treat a variety of bacterial infections of the eye and skin. It has the following chemical structure:

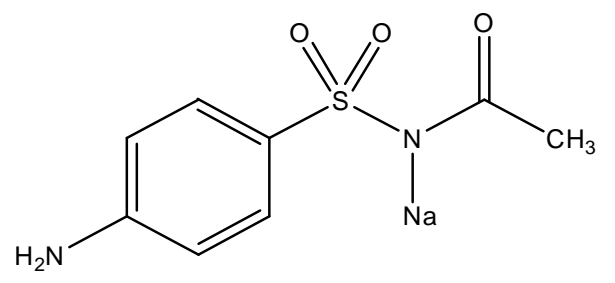

A number of methods were used for the quantitative determination of sulfacetamide. HPLC method with average recoveries $98.9 \%(\mathrm{n}=5)$ and $\mathrm{RSD}=0.64 \%$ (Xu et al.,1999), liquid chromatography the limit of detection was (0.002) $\mathrm{mg} \mathrm{kg}^{-1}$ (Pang et al.,2003), differential-pulse polarography with an experimental detection limit of $\left(2.4 \times 10^{-}\right.$ $\left.{ }^{6}\right) \mathrm{M}$ in aqueous solution (Sulaiman et al.,1989), specrophotometric methods: Beer's law is obeyed in the concentration range of (0.04-8.0) $\mathrm{microg} / \mathrm{ml}$ at the wavelength of maximum absorption (Nagaraja et al.,2002). The Beer's law limits is (4-80) $\mu \mathrm{g} / \mathrm{ml}$ (Amin and Zareh,1996), Beer's law is obeyed over the concentration range 10 to $70 \mathrm{mug} / \mathrm{ml}$ (Rao et al.,1988) and first-order derivative spectrophotometry (Abdellatef et al.,1989).

In this work, the direct quantification of sulfacetamide was accomplished using the integrated area under the peaks within a range of wavelengths, the peak area measurements are often found to be more reliable than peak height measurements (Cottrell,1989).

\section{EXPERIMENTAL}

Chemicals and solutions:

1. Pure Sulfacetamide Sodium (SDI) :

A stock solution of $\left(10^{-3}\right) \mathrm{M}$ was prepared by dissolving (0.0118) $\mathrm{g}$ of pure sulfacetamide in $50 \mathrm{ml}$ distilled water, then by proper dilution, other less concentrated solutions were prepared.

2. Pure Sodium Thiosulfate :

A stock solution of $\left(10^{-3}\right) \mathrm{M}$ was prepared by weighing (0.0076) $\mathrm{g}$ of sodium thiosulfate $\left(\mathrm{Na}_{2} \mathrm{~S}_{2} \mathrm{O}_{3}\right)$ and dissolving in $50 \mathrm{ml}$ distilled water then by proper dilution, other more dilute concentrations were prepared.

3. Sulfacetamide Drug Solution :

SAMACETAMIDE eye drops (SDI, Iraq, sulfacetamide sodium, 20\%, sodium thiosulfate, $0.1 \% \mathrm{w} / \mathrm{v}$ ): The molar concentration of the eye drop(SAMACETAMIDE 20\%) was calculated (0.8467) $\mathrm{M}$ and then by proper dilution with distilled water, other more dilute solutions were prepared and their spectra were recorded. 
A Shimadzu UV-Visible spectrophotometer model UV-1650 PC, connected to a computer with pentium 4 processor. The optimized conditions for spectrophotometic measurements were derivative modes ${ }^{1} \operatorname{Dr}\left(\mathrm{d}^{1} \mathrm{~A} / \mathrm{d} \lambda^{1}\right),{ }^{2} \operatorname{Dr}\left(\mathrm{d}^{2} \mathrm{~A} / \mathrm{d} \lambda^{2}\right)$, scan speed fast, slit width $2 \mathrm{~nm}$, derivative UV spectra were recorded over a wavelength range of (200-400) $\mathrm{nm}$, using $(1 \times 1 \times 3) \mathrm{cm}$ matched quartz cells.

\section{RESULTS AND DISCUSSION}

The zero-, first- and second-order derivative spectra of pure sulfacetamide in distilled water for a series of different concentrations $\left(1 \times 10^{-6}-2 \times 10^{-4}\right) \mathrm{M}$, were recorded. The zero-order spectrum shows an absorption at $\lambda=258 \mathrm{~nm}$ with a molar absorptivity of about $149001 \mathrm{lmol}^{-1}$. $\mathrm{cm}^{-1}$. The plot of the recorded absorbance against the molar concentration of pure sulfacetamide results in a straight-line obeying the Beer's law within a concentration range of $\left(2.151 \times 10^{-6}-1.075 \times 10^{-4}\right) \mathrm{M}$, corresponding to a determination limit of $(0.55-25.4) \mu \mathrm{g} / \mathrm{ml}$, with $\mathrm{R}^{2}=0.9999$, and $\mathrm{RSD}=1.25 \%$ (Table 1, Figs. 2,3 ).

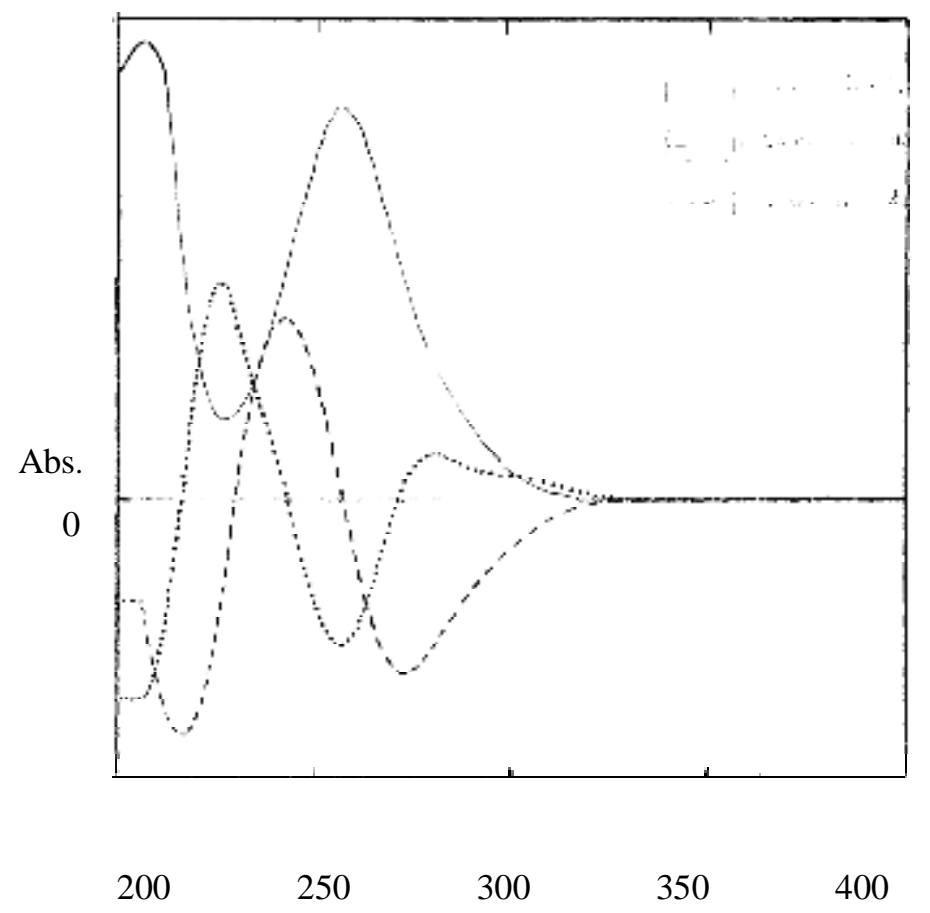

Fig.2: The UV absorption (zero(_ ), first ( -----) and second (....... ) -order derivative spectra of $\left(5.377 \times 10^{-5}\right) \mathrm{M}$ of pure sulfacetamide sodium solution 


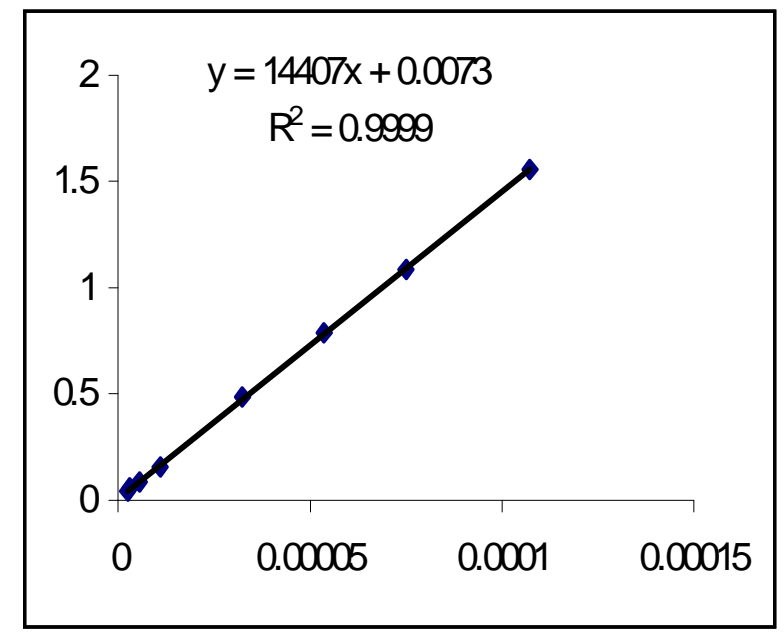

Fig. 3: The calibration curve of the zero-order spectrumof pure sulfacetamide solutions.

Table1: The absorbance of the zero-order spectra at $\lambda=258 \mathrm{~nm}$ for different concentrations of pure sulfacetamide solutions in water

\begin{tabular}{|c|c|}
\hline Molar Concentration & Absorbance \\
\hline $2.151 \times 10^{-6}$ & 0.036 \\
\hline $3.226 \times 10^{-6}$ & 0.051 \\
\hline $5.377 \times 10^{-6}$ & 0.082 \\
\hline $1.075 \times 10^{-5}$ & 0.161 \\
\hline $3.226 \times 10^{-5}$ & 0.480 \\
\hline $5.377 \times 10^{-5}$ & 0.791 \\
\hline $7.528 \times 10^{-5}$ & 1.087 \\
\hline $1.075 \times 10^{-4}$ & 1.553 \\
\hline
\end{tabular}

The applications were accomplished by recording the zero-order spectra of SAMACETAMIDE eye drop ( $20 \%$ sulfacetamide sodium, $0.1 \%$ sodium thiosulphate w/v) which resemble the spectra of pure sulfacetamide, at $\lambda=(256-258) \mathrm{nm}$ at different concentrations of sulfacetamide in SAMACETAMIDE eye drop and the absorbance were plotted against the molar concentration. The result was a straight-line over the concentration ranges $\left(1.100 \times 10^{-6}-1.100 \times 10^{-4}\right) \mathrm{M}$ with $\mathrm{R}^{2}=0.9974$, The recovery percent is estimated (Table 2). 
Table 2: The absorbance of the zero-order spectrum at $\lambda=258 \mathrm{~nm}$ for different concentrations of sulfacetamide in SAMACETAMIDE eye drop solutions

\begin{tabular}{|c|c|c|c|}
\hline $\begin{array}{c}\text { Molar Concentration } \\
\text { (Taken) }\end{array}$ & Absorbance & $\begin{array}{c}\text { Molar } \\
\text { Concentration } \\
\text { (Found) }\end{array}$ & Recovery \% \\
\hline $5.503 \times 10^{-6}$ & 0.085 & $5.439 \times 10^{-6}$ & 98.8 \\
\hline $1.100 \times 10^{-5}$ & 0.159 & $1.057 \times 10^{-5}$ & 96.1 \\
\hline $5.503 \times 10^{-5}$ & 0.933 & $6.427 \times 10^{-5}$ & 116.8 \\
\hline $1.100 \times 10^{-4}$ & 1.702 & $1.176 \times 10^{-4}$ & 106.9 \\
\hline
\end{tabular}

It is worth mentioning that the presence of $0.1 \% \mathrm{w} / \mathrm{v}$ sodium thiosulphate as additive in the solution of the sulfacetamide eye drop has no effect on the quantitative determination of the sulfacetamide, since the spectra of pure sodium thiosulfate and sulfacetamide eye drop at the different concentrations were recorded (Fig. 4). From the spectra, it is clear that there is negligible influence in changing the absorbance at $\lambda=258 \mathrm{~nm}$ at which sulfacetamide absorbs and is determined.

The first-order derivative spectrum of pure sulfacetamide shows a positive peak at $\lambda=$ (232-258) $\mathrm{nm}$, crossing the zero-axis at $\lambda=258 \mathrm{~nm}$ and a negative peak at $\lambda=(258-326)$ $\mathrm{nm}$. The quantitative determination of pure sulfacetamide was accomplished through plotting of a calibration curve between the integrated area under the positive peak against the molar concentration of pure sulfacetamide solutions. The result was a straight- line obeying the Beer-Lambert law with a determination limit of (0.25-50.80) $\mu \mathrm{g} / \mathrm{ml}, \mathrm{R}^{2}=$ 0.9982 and $\mathrm{RSD}=1.60 \%$ (Fig. 5). 
Direct Determination of Sulfacetamide Sodium.

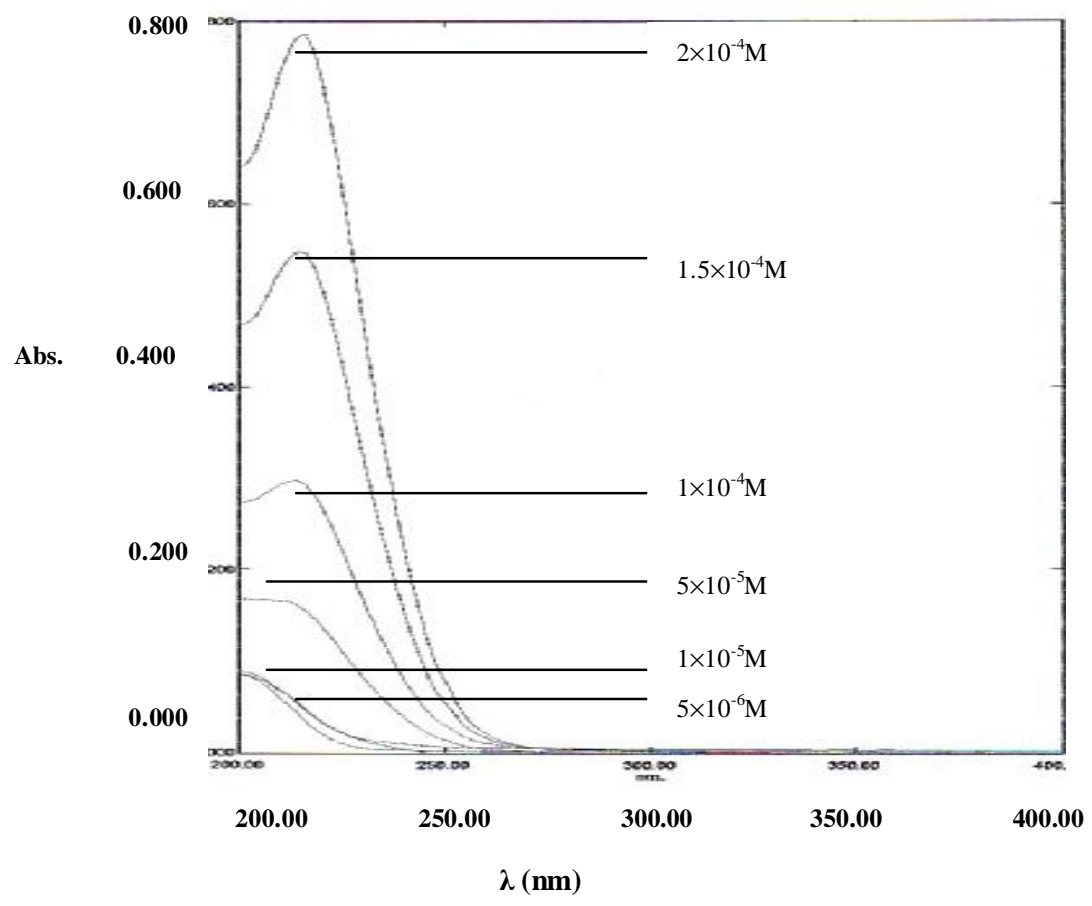

Fig. 4: The zero-order overlay spectra for different concentration of pure sodium thiosulphate solutions in water

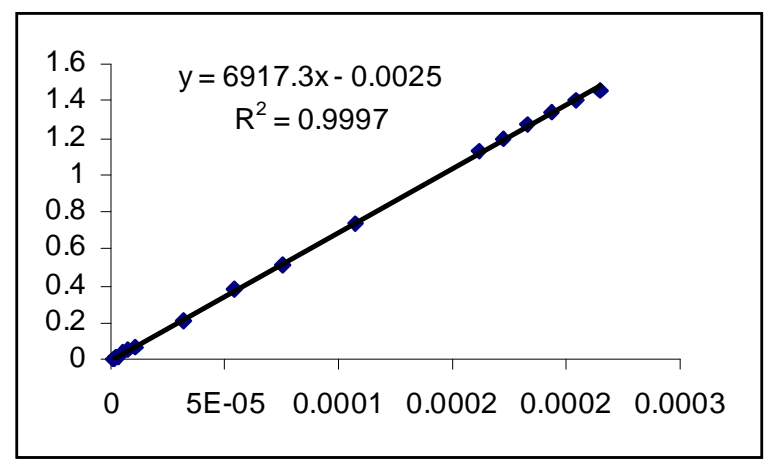

Fig. 5: The calibration curve of the first-order derivative spectrum of pure sulfacetamide solutions

The first-order derivative spectrum for SAMACETAMIDE drug solutions recorded at different concentrations and the area under the positive peak at $\lambda=(230-258) \mathrm{nm}$ was integrated and the recoveries were estimated (Table 3). 
Table 3: The integrated area under the positive peak of the first-order derivative spectra at $\lambda=(230-258) \mathrm{nm}$ for different molar concentration of SAMACETAMIDE eye drop solutions.

\begin{tabular}{|c|c|c|c|}
\hline $\begin{array}{c}\text { Molar } \\
\text { Concentration } \\
\text { (Taken) }\end{array}$ & $\begin{array}{c}\text { Integrated } \\
\text { Area }^{*}\end{array}$ & $\begin{array}{c}\text { Molar } \\
\text { Concentration } \\
\text { (Found) }\end{array}$ & Recovery\% \\
\hline $1.100 \times 10^{-6}$ & 0.008 & $1.144 \times 10^{-6}$ & 103.9 \\
\hline $5.503 \times 10^{-6}$ & 0.040 & $5.749 \times 10^{-6}$ & 104.5 \\
\hline $1.100 \times 10^{-5}$ & 0.073 & $1.049 \times 10^{-5}$ & 95.4 \\
\hline $5.503 \times 10^{-5}$ & 0.405 & $5.828 \times 10^{-5}$ & 105.9 \\
\hline $1.100 \times 10^{-4}$ & 0.815 & $1.172 \times 10^{-4}$ & 106.6 \\
\hline $1.431 \times 10^{-4}$ & 1.013 & $1.457 \times 10^{-4}$ & 101.9 \\
\hline $1.651 \times 10^{-4}$ & 1.170 & $1.683 \times 10^{-4}$ & 101.9 \\
\hline $1.871 \times 10^{-4}$ & 1.324 & $1.905 \times 10^{-4}$ & 101.8 \\
\hline $2.201 \times 10^{-4}$ & 1.473 & $2.119 \times 10^{-4}$ & 96.3 \\
\hline
\end{tabular}

The spectrum of the second-order derivative for different concentrations of pure sulfacetamide show a negative peak at $\lambda=(242-274) \mathrm{nm}$ (Fig. 1), their integrated area were plotted against the molar concentrations the result is a straight-line relationship obeying the Beer-Lambert law with a determination limit of $(0.25-50.80) \mu \mathrm{g} \backslash \mathrm{ml}, \mathrm{R}^{2}=0.9995$, and RSD $=2.40 \%$ (Fig. 6).

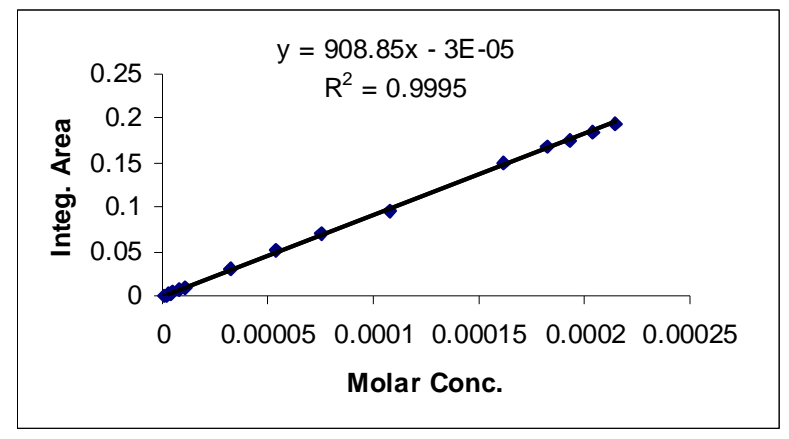

Fig. 6: The calibration curve of the second-order derivative spectra of pure sulfacetamide solutions. 
The second-order derivative spectra of a series for SAMACETAMIDE drug solution show a negative peak at $\lambda=(242-274) \mathrm{nm}$. The areas are integrated and the recoveries for them were estimated (Table 4).

Table 4: The integrated area under the negative peak of the second-order derivative spectra at $\lambda=(242-274) \mathrm{nm}$ for different concentration of SAMACETAMIDE eye drop solutions.

\begin{tabular}{|c|c|c|c|}
\hline $\begin{array}{c}\text { Molar } \\
\text { Concentration } \\
\text { (Taken) }\end{array}$ & $\begin{array}{c}\text { Integrated } \\
\text { Area }\end{array}$ & $\begin{array}{c}\text { Molar } \\
\text { Concentration } \\
\text { (Found) }\end{array}$ & Recovery \% \\
\hline $1.100 \times 10^{-6}$ & 0.001 & $1.133 \times 10^{-6}$ & 102.9 \\
\hline $5.503 \times 10^{-6}$ & 0.005 & $5.534 \times 10^{-6}$ & 100.6 \\
\hline $1.100 \times 10^{-5}$ & 0.010 & $1.104 \times 10^{-5}$ & 100.3 \\
\hline $5.503 \times 10^{-5}$ & 0.050 & $5.505 \times 10^{-5}$ & 100.1 \\
\hline $1.100 \times 10^{-4}$ & 0.103 & $1.134 \times 10^{-4}$ & 103.1 \\
\hline $1.431 \times 10^{-4}$ & 0.132 & $1.453 \times 10^{-4}$ & 101.5 \\
\hline $1.651 \times 10^{-4}$ & 0.154 & $1.695 \times 10^{-4}$ & 102.6 \\
\hline $1.871 \times 10^{-4}$ & 0.175 & $1.926 \times 10^{-4}$ & 102.9 \\
\hline $2.201 \times 10^{-4}$ & 0.192 & $2.113 \times 10^{-4}$ & 95.9 \\
\hline
\end{tabular}

\section{CONCLUSIONS}

The second-order derivative method was the best method for the quantitative determination of pure sulfacetamide as compared with the zero and first-order methods. The same results proved fruitful for the determination of sulfacetamide in the eye drop SAMACETAMIDE (the best recovery percent and the minimum percent of error), even though that sulfacetamide was determined by first-order derivative according to peak height recording whereas in this work the integrated area under the peak was employed which more reliable for quantification. The determination limit of sulfacetamide was improved by using derivative spectrophotometry than the normal spectra.

\section{REFERENCES}

Abdellatef, H.; Elbalkiny, M.; Aboulkheir, A.(1989). Determination of sulfacetamide, sulfadimidine or sulfathiourea in the presence of their degradation products using first derivative spectrophotometry. Pharm. Biomed. Anal., 7 (5), 571-576.

Amin, A. S.; Zareh, M. M. (1996). Acetylacetone-formaldehyde reagent for the spectrophotometric determination of some sulfa drugs in pure and dosage forms. Mikrochim. Acta, 124 ( 3-4), 227-233.

Cottrell, C. T. (1989). Derivative and log spectrophotometry, Ph. D. Thesis, Pye Unicam Ltd, Cambridge.

Himmadi, I. A. (2007). Derivative UV spectra studies of some drugs-application to trace determination, M. Sc. Thesis, College of Science, University of Mosul. 
Maffat, A. C.; Osselton, M. D.; Widdop, B. (2005). "Clarke's Analysis of Drugs and Poisons".3rd edn, London, Pharmaceutical Press, Electronic verssion.

Nagaraja, P.; Yathirajan, H.; sunitha, K.; Vasantha, R. (2002). A new, sensitive, and rapid spectrophotometric method for the determination of sulpha drugs. $A O A C$ International, 85 (4), 869-874.

Pang, G. F.; Gao, Y. Z.; Fan, C. L.; Zhang, J. J.; Li, X. M.; Li, Z. Y.; Jia, G. Q. (2003). Liqiud chromatography-fluoresence detection for simultaneous analysis of sulfonamide residues in honey. Anal. and Bioanal. Chem., 376 ( 4), 534-541.

Rao, G. R.; Murty, S.; Rao, P. J.; Raju, I. (1988). Spectrophotometric determination of sulphacetamide sodium with o-chloranil in dosage forms. Pharm. Sci., 50( 2 ), 138-140.

Sulaiman, S. T.; Al-Nuri, I. J.; Al-Abachi, M. O. (1989). Differential Pulse polarographic behavior of diazonium salts derived from some sulfonamide derivativesapplication to the trace detirmnation of nitrite and some sulfonamide drugs. Iraqi J. Chem., 14 (1), 58-61.

Xu, S.; Wu, L.; Se, p.( 1999). determination of sulfacetamide sodium and sulfanilamide in shao tang ling ointment by high performance liquid chromatography. Pub Med, 17 (2), 206-207. 